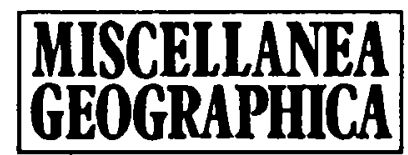

WARSZAWA 1994 Vol. 6

Dorota Raubo

\title{
NEW SETTLEMENTS IN THE FARAFRA OASIS
}

Desert recultivation in the region of Farafra (Qasr el-Farafra) was undertaken in two stages. In the 1960 s, carrying out the Naserist project of the "New Valley", 13 shallow and 18 deep water wells were drilled. More widely they were exploited only from the beginning of the 1980s, when the irrigation of desert land and building of new villages were commenced. At that time, new wells were drilled, too, which brought up their number to the total of 88 .

At present, 5 villages are in operation from the number of 20 projected by the Ministry of Agriculture. Al-Nahda (The Renaissance), situated northwest of Qasr el-Farafra, was the first one to have been built and settled. Its construction started in 1981 and the first 3 families moved from Qasr elFarafra already in that year. Since that time, gradual immigration of the settlers has continued from Dakhla, Kharga and Upper Egypt, but also from Cairo. At present, the village is inhabited by about 600 persons, chiefly fellahs (peasants), who are cultivating ca 1,300 ha of agricultural land.

At the village of Ellwa Sobaih, lying west of Qasr el-Farafra, the first families settled in 1988. The settlers come from Upper Egypt mainly. In the village there live about 500 people. The acreage under cultivation amounts to 1,300 ha. In the near future, the further 600 ha are to be taken under cultivation.

The villages of el-Kefah and Abu Horayra (25 and $35 \mathrm{~km}$ south of Qasr el-Farafra respectively) have been in the course of construction since 1989. However, the settling of the newcomers in these villages began already two years ago, when they were still far from being completed. At present, elKafah has some 200 people and Abu Horayra about 180. In either of the villages 800 ha have been reclaimed for cultivation and the figure is planned to reach 1,300 ha.

The principles of the village organization are the same everywhere. All settlers are getting lodgings from the authorities, with one difference though: lodgings for settlers with a university degree are better than those for simple peasants. In the village of Ellwa Sabaih, administration employees live in a separate building. Furthermore, the government builds 
a school, a hospital and a mosque in each village. However, the construction of these public buildings is always delayed. At al-Nahda, for instance, the school was finished only in 1991. As a result, the children had to be driven to school at Qasr el-Farafra for 10 years. The new school is fairly big. It employs 23 teachers many of whom come to work from Qasr el-Farafra and some even from Dakhla. They are teaching 90 pupils.

The hospital was built 3 years ago and it has stayed empty ever since. There is a nurse in the village and a doctor comes once a week.

At Ellwa Sobaih the school was finished in 1990. At present, there are 6 teachers working there, including one coming from the outside. It is worth mentioning that these 6 persons teach a group of only 10 pupils. The village has a hospital building, so far unused.

In the newest villages of El-Kefah and Abu Horeyra, schools are still under construction. Their completion is expected after a year. Construction of hospitals figures in plans, but it has not been commenced as yet.

Electrification of all villages is financed by the central administration. The government pays also for the energy during the first four years. Later on, half of the energy costs are covered by the inhabitants. The electric current is supplied only on a part-time basis (from 18 to 24 o'clock).

The government also takes on a duty to supply private houses with water, but there is not always enough money. At Ellwa Sabaih the watersupply system has not yet been completed, which is the reason for much complaint from the inhabitants. Likewise, there is not enough money for the maintenance and repairing of the sewage system as well as of the electric network. At al-Nahda there has been no water in private houses for the last two years because the pump had been broken. The authorities have no funds to repair it and there is little chance that they will get them in the future. As a result, water can be obtained only from the public intakes in the street. During the first five years after the settlement water is free. Later on, the inhabitants have to pay full costs.

Land distribution remains in the hands of the Ministry of Agriculture jointly with the local administration. Preferences for assignments are given to candidates educated in agriculture, to the Farafrans and to enterprising young people. The average size of allotted farms is 8 feddans ( 1 feddan $=$ $0.42 \mathrm{ha}$ ), but more land can be taken on lease or purchased. Some agricultural engineers own as much as 20 feddans. Teachers and administration officials are not assigned land but can take it on lease. The rent for leased land is 80 Egyptian pounds per feddan.

The authorities do not impose the cultivation pattern. The main crops include wheat (in winter), rice (in summer), broad beans, peas, beans, onion, and maize. There are few vegetables and fruit trees. A large proportion of produced crops is used for domestic needs. The surplus of products yielded by farms is sold to the bank at Qasr al-Farafra, where fertilizers can also be obtained. Agricultural machines are usually rented from the 
state centre of agricultural machinery, which is found in each village. Only a small number of farmers own machines (chiefly tractors).

Housing as well as arable land is sold to the settlers on credit to be paid back by instalments within 35 years. But during the first five years the government does not charge the settlers with payments. On the contrary, it helps them to start running farms in the new environment. Hence free electricity and water as mentioned above.

All farmers with a university degree receive 50 Egyptian pounds per month for 2 to 4 years. In addition, each family receives from the government a monthly sustenance help in kind (flour, cheese, sugar, rice, oil, tea, butter etc.). After five years since the settlement the governmental assistance ends and the settlers are obliged to pay the credit back. It happens, however, quite often that they cannot discharge themselves of liabilities. In such cases, if the reasons are beyond their control, the authorities adjourn the payment of credits.

In spite of the protective policies of the government, the new villages do not seem to arouse the expected interest. A number of the houses constructed remain uninhabited. Especially settlers coming from the Nile Valley complain about difficult living conditions in the desert. Newcomers from other oases adapt themselves to the local conditions more easily.

Transportation is one of the most important problems of the newly built villages. Despite the construction of road linking them with Qasr el-Farafra and farther on with other oases, there is a total absence of bus services. The inhabitants have to depend on their own means of transportation which are very limited. At el-Nahda there are three cars, at Ellwa Sobaih there is none. Tractors, motor bikes and donkeys are chiefly used for transportation. Inadequate transport hampers development of trade. It is one of the reasons why peasants do not plant vegetables and fruit trees and are forced to sell their surplus crops to the bank which pays low, official prices. Likewise, the expansion of trade in the new villages has little prospects. The farmers, having no chance to sell their products outside their villages, are producing foodstuffs to meet their own needs mainly; therefore they do not have to use commercial services of shops. In each village there is only one shop. 